\title{
The Development Status, Problems and Countermeasures of China's Carbon Financial Market
}

\author{
Yifan Yuan \\ School of Economics, Jinan University, Guangzhou, China \\ Email: 1213339439@qq.com
}

Received 22 February 2016; accepted 27 March 2016; published 30 March 2016

Copyright (C) 2016 by author and Scientific Research Publishing Inc.

This work is licensed under the Creative Commons Attribution International License (CC BY). http://creativecommons.org/licenses/by/4.0/

(c) (i) Open Access

\begin{abstract}
In recent years, the global climate governance is not just for a global environmental problem of climate change, more involved in international politics, economy, investment, technology and other fields, and involves the transformation of production and life style. Accompanied by global energy and technology revolution, the development of low carbon is our inevitable requirement. Recently, China submitted to UNFCCC (United Nations Framework Convention on Climate Change) the Secretariat of the national independent contribution plan and set emission reduction targets: carbon dioxide emissions reach the peak in $\mathbf{2 0 3 0}$ and strive to reach the peak as early as possible; carbon emission intensity decreased by $60 \%-65 \%$ compared with that in 2005 . This means that our government will intensify its efforts to reduce carbon emissions. In the past, our target was to reduce carbon emissions intensity, but now our country is to realize the reduction of total carbon emissions, or "absolute reduction". Carbon finance is an important breakthrough in the development of low carbon economy and the promotion of carbon emission reduction. This paper focuses on the analysis of the development status of China's carbon financial market, the problems and the opportunities and challenges faced, and finally, the relevant countermeasures and suggestions are given from the perspectives of policy, talent, mechanism, international cooperation and so on, in order to promote the development of carbon financial market innovation, to seize the commanding heights of the era of low-carbon economy.
\end{abstract}

\section{Keywords}

Carbon Finance, Carbon Emissions, Low Carbon Economy, Current Situation, Problems

\section{Introduction}

Extreme weather has become increasingly frequent; the seriousness of the problem of climate change issue can- 
not be ignored. Developing low carbon economy is the way to solve the problem of climate, the trend of global economic development, the inevitable requirement of promoting Chinese economic transformation and upgrading of the industrial structure, and one of the important ways and means of placing on the "Chinese dream" and realizing the "Chinese dream".

Low carbon economy development cannot lack financial support, accompanied by the development of carbon finance market. In December 1997, 159 parties of the United Nations framework convention on climate change signed the "Kyoto protocol". The Kyoto protocol took effect in February 2005; it requires 38 OECD countries, the national group and some countries in the economic transition period to make carbon dioxide and other six kinds of greenhouse gas emission reduction targets. Since the carbon emission rights has gradually become a scarce resource, carbon trading market also developed rapidly, derived from the relevant financial needs. At present, as the emissions trading schemes, cap-and-trade policy, and other measures are improving, carbon finance has gradually become an effective way to reduce carbon emissions and promote the development of low carbon economy in the world. China ranked "carbon emitting countries". It is necessary to explore the efficient financial support tools and methods, and gradually establish and improve the carbon finance system with the characteristics of our country.

\section{Analysis of Carbon Finance Market in China}

\subsection{Carbon Finance Definition}

Both domestic and international academic circles have not given a unified definition of "carbon finance", different parties expressed different. Summary of the economist's point of view, "carbon finance" refers to the economic behavior of enterprises on the market exchange of the greenhouse gas emission rights allocated by the government, and financial institutions involved in the activities of the financial institutions involved in the relevant financial activities [1]. World Bank "carbon finance ten years", carbon finance described as selling based on the project's greenhouse gas reduction displacement or carbon emissions trading permits to obtain a series of cash flow collectively.

\subsection{The Development of China's Carbon Finance}

According to the "Kyoto Protocol" agreement, China as a developing country, there is no emission reduction obligations, so our country in the international carbon financial market mainly through CDM project in the two level market to provide CERs, and access to financial and technical support from developed countries. However, China actively promotes the development of carbon finance, starting carbon emissions trading pilot in 2013, made good progress.

\section{1) Current Status CDM Projects in China}

The clean development mechanism (CDM) project is the basis for developing countries to participate in global carbon trading market. According to the national development and Reform Commission's statistics, as of May 5, 2015, China approved a total of 5073 clean development mechanism projects, expected annual emission reductions are about 780 million tons of carbon dioxide equivalent, mainly focused on new energy and renewable energy, energy conservation and energy efficiency, methane recovery and utilization, and so on, which is shown in Table 1.

Among them, 3807 projects have been successfully registered in the implementation of the United Nations Clean Development Mechanism, accounting for $49.5 \%$ of total registered projects around the world, registered projects are expected average annual CERs (CER) of about 620 million tons of carbon dioxide equivalent, over the global registry project emission 60\%, project numbers and average annual CERs are ranked first in the world. The rapid development of the CDM project shows that China has taken a big step in the development of carbon finance [2].

\section{Table 1. Table type styles.}

\begin{tabular}{ccccccccc}
\hline Types & $\begin{array}{c}\text { Energy } \\
\text { conservation } \\
\text { and efficiency }\end{array}$ & $\begin{array}{c}\text { Methane } \\
\text { recovery and } \\
\text { utilization }\end{array}$ & $\begin{array}{c}\text { Garbage } \\
\text { incineration } \\
\text { power }\end{array}$ & $\begin{array}{c}\text { New \& } \\
\text { renewable } \\
\text { energy }\end{array}$ & $\begin{array}{c}\text { N20 } \\
\text { elimpositionation }\end{array}$ & $\begin{array}{c}\text { Afforestation } \\
\text { and } \\
\text { reforestation }\end{array}$ & $\begin{array}{c}\text { Fuel } \\
\text { substitution }\end{array}$ & $\begin{array}{c}\text { HFC-23 } \\
\text { decomposition }\end{array}$ \\
Others \\
Num & 256 & 237 & 34 & 3173 & 43 & 4 & 28 & 21 \\
\hline
\end{tabular}




\section{2) Current Status VER Projects in China}

VER project is a voluntary emission reduction mechanism, mainly for some enterprises or individuals to fulfill their social responsibility and voluntary carbon emission reduction and carbon trading. Voluntary emission reduction is relatively loose, the current market size is small, has not yet formed a unified international standard, the main participants are some of the relatively large enterprises or institutions. For example, the green travel Beijing Olympic Games, Shanghai World Expo voluntary emission reduction platform, the Industrial Bank's low carbon credit cards, etc. are different forms of VER.

Template is used to format your paper and style the text. All margins, column widths, line spaces, and text fonts are prescribed; please do not alter them. You may note peculiarities. For example, the head margin in this template measures proportionately more than is customary. This measurement and others are deliberate, using specifications that anticipate your paper as one part of the entire journals, and not as an independent document. Please do not revise any of the current designations.

\section{3) Current Status of Carbon Trading Platform}

2011, Chinese government established carbon emissions trading pilot in Shanghai, Beijing, Tianjin, Chongqing, Guangdong and Hubei. 2013, as the first year of carbon trading in China, five provinces and cities, Beijing, Tianjin, Shanghai, Guangdong and Shenzhen has launched a local carbon trading pilot and produced a local quota trading and price, Hubei and Chongqing were also open carbon trading market in the first half of 2014. In all the pilot, only in Shanghai, the 191 carbon emissions trading pilot enterprises are all on time to submit a corporate 2013 annual carbon emissions Report In March 31, 2014. Reporting completion rate reached 100\%.

Pilot carbon trading in China has entered a substantive stage of the transaction, and been gradually perfected carbon trading policies and regulations. Mean while activities based on projects and quotas have been launched, through carbon trading market, the corresponding technology and ability level has been improved. The whole mechanism of carbon price movement began to start, more and more enterprises and voluntary emission reduction are included in the transaction activities, which has laid the foundation for the development of the national carbon trading and the international practice.

\subsection{Opportunity of China's Carbon Finance Development}

China carbon financial is in industry chain of minimum end, this may be an essential stage [3], but in global climate changes situation severe, Paris climate conference reached new of agreement, and China huge of carbon emissions right trading needs and in CDM project's unique advantage background, China carbon financial markets' development and innovation ushered in rare of history opportunities, and can master more of initiative in international economic, and financial system heavy frame process.

On the one hand, international cooperation and the transformation of low-carbon economy can create more space and opportunities. Extreme weather becomes worse in the world, the environment continues to deteriorate, and the situation is not optimistic, many countries have taken action, trumpeting to develop low-carbon economy. International climate negotiations are ongoing, on December 12, 2015, climate conference in Paris reached at the New Testament, breakthrough, which is the first legally binding agreement adopted by all parties, further defining climate governance is in an important position in global development, this provide precondition to international carbon market system's constant improvement. China's economy also stressed that "growth" to "development", stressed the content of "quality", coinciding with the opportunity of China's transition to a low carbon economy, China market has great potential, which lay the necessary conditions for development of China carbon markets [4].

On the other hand, global carbon credit market is huge, and CDM project in China is rich in resources. Post Kyoto era, global carbon markets greatly expanding, not only the European Union, United States, and Australia and other countries are important buyers of carbon markets [5]. According to a Bloomberg new energy finance database grooming, which is shown in Table 2, 2013-2020's carbon credit trading giant, in which China's position.

Table 3 shows that global carbon credit market is in short supply, and on the supply side is good for China, and China occupies a good position in the supply market as a whole. Our country has been through the CDM mechanism provides certified carbon credits to developed countries CERS, CDM project is very rich in resources. According to the national development and Reform Commission's statistics, as of May 5, 2015, China approved a total of 5073 clean development mechanism projects, expected annual emission reductions are about 
Table 2. 2013-2020 global carbon credit demand (unit: million tons of carbon dioxide).

\begin{tabular}{ccccccccccc}
\hline & 2013 & 2014 & 2015 & 2016 & 2017 & 2018 & 2019 & 2020 & Total \\
\hline EU & 419 & 359 & 354 & 255 & 120 & 63 & 63 & 63 & 1696 \\
USA-electricity sector & 40 & 54 & 74 & 81 & 122 & 187 & 251 & 301 & 1110 \\
Australia & 25 & 30 & 34 & 40 & 43 & 42 & 42 & 42 & 298 \\
Japan & 24 & 122 & 122 & 122 & 122 & 122 & 122 & 122 & 878 \\
Canada & & 10 & 10 & 10 & 10 & 10 & 10 & 10 & 70 \\
Others & 22 & 26 & 26 & 27 & 33 & 33 & 33 & 34 & 234 \\
USA-potential demand & 43 & 59 & 223 & 276 & 286 & 273 & 275 & 306 & 1741 \\
Total (USA-power sector) & 531 & 601 & 620 & 508 & 450 & 458 & 521 & 573 & 4262 \\
Total (USA-global economy) & 574 & 660 & 843 & 784 & 736 & 730 & 796 & 879 & 6002 \\
\hline
\end{tabular}

Source: according to Peng Boxin Energy Financial database.

Table 3. 2013-2020 global carbon credit supply (unit: million tons of carbon dioxide).

\begin{tabular}{|c|c|c|c|c|c|c|c|c|c|}
\hline Unit: $\mathrm{MtCO}_{2}$ & 2013 & 2014 & 2015 & 2016 & 2017 & 2018 & 2019 & 2020 & Total \\
\hline China & 277 & 267 & 212 & 178 & 141 & 117 & 112 & 109 & 1413 \\
\hline India & 71 & 50 & 42 & 48 & 44 & 35 & 32 & 29 & 352 \\
\hline Central Asia & 8 & 3 & 7 & 11 & 9 & 8 & 8 & 9 & 63 \\
\hline other parts of Asia & 54 & 29 & 33 & 47 & 42 & 35 & 34 & 34 & 307 \\
\hline America & 28 & 62 & 34 & 44 & 36 & 30 & 30 & 30 & 294 \\
\hline Africa & 11 & 21 & 17 & 25 & 22 & 19 & 19 & 19 & 154 \\
\hline Europe & 0 & 0 & 2 & 4 & 4 & 3 & 3 & 4 & 20 \\
\hline Middle East & 4 & 2 & 6 & 11 & 10 & 8 & 9 & 9 & 59 \\
\hline Russia & 0 & 0 & 7 & 14 & 12 & 10 & 11 & 11 & 64 \\
\hline Total & 453 & 434 & 361 & 383 & 320 & 266 & 258 & 254 & 2729 \\
\hline Others & 18 & 23 & 21 & 31 & 38 & 61 & 90 & 119 & 401 \\
\hline Total & 471 & 457 & 382 & 414 & 358 & 327 & 348 & 373 & 3130 \\
\hline
\end{tabular}

Source: according to Peng Boxin Energy Financial database.

780 million tons of carbon dioxide equivalent, mainly focused on new energy and renewable energy, energy conservation and energy efficiency, methane recovery and utilization, and so on.

Of which, 3807 projects have been successfully registered by the Executive Board of the clean development mechanism of the United Nations, accounting for $49.5 \%$ of total registered projects around the world, registered projects are expected average annual CERs (CER) of about 620 million tons of carbon dioxide equivalent, over the global registry project emission $60 \%$, project numbers and average annual CERs are ranked first in the world. Carbon finance development in China has provided a good basis, we should make full use of this.

\section{The Carbon Financial Challenges and Problems of China}

Despite the development of carbon finance comes at the time, China also has its own advantages. But in China, carbon finance started late, compared with developed countries large behind. To have greater development we still have many problems: carbon markets are not perfect, policies are not comprehensive, mechanisms set and goals achieved have a great gap and so on [6]. 
1) Policy system is not perfect, the relevant laws and regulations are not complete [7]. China's domestic carbon financial policy formulation is scattered, slow policy, lack of global perspective, inconsistent with the current rapid development of carbon markets. First, the government lacks the awareness of low-carbon, all sectors and all levels of government treat low-carbon economy and carbon financial is inconsistent, such as the central ministries are more active than local governments, the government is more active than enterprises, the government officials are more active than the general population. Policy support to low-carbon economy and carbon finance knowledge is not sufficient [8]. Second, tax policies are not in place, many low-carbon projects are not eligible for credit or private equity funds, venture capital investments and solve Fund bottleneck problem in the development is the most important issue. Third, the Government has not begun the regulatory research in carbon finance. China's carbon market development will be fast undoubtedly, which will produce large amounts of carbon finance risk, so the carbon finance regulatory issues will be the future basis for the effective implementation of the protection market. Finally, the strength of reduction system is in sight. Domestic emission reductions have already been written on strength "Twelve-Five” planning, but execution and evaluation standards are not published, which severely inhibited the development of strength reduction in China [9].

2) Carbon markets split is serious at present, uniform international carbon markets have not yet formed, carbon trading mostly concentrated in a few countries or inside a certain region, there is no uniform standard. Diversification the carbon trading market which not only has numerous exchanges but has over-the-counter mechanism; the markets controlled by the Government and the participation in the formation of voluntary market is also included. Most of these markets are based on countries and regions, there is a big difference in the institutional arrangements in the relevant market, direct cross-market trading between different markets. Carbon financial markets are in the highly fragmented state, market efficiency is quite low [10]. Therefore, the carbon market participants need to strengthen cooperation and integration under the effective guidance of the Government.

3) The intermediary market is not perfect. China's carbon market is still in its infancy stage, lacking a large number of professional intermediaries and professionals. For the clean development mechanism projects which account for a large proportion of our carbon trading market now, the status presented are that the project development cycle is long, average project life is about 5 years; approval process is complex and need to be approved by both domestic and international. Policy update frequency quickly, which led the development process shows variability, thus registering higher risks. So the high expectations for the employees and practitioners are needed to comprehensive grasp on economic, environmental, legal, foreign languages and other related expertise. However, China's reserves of such professionals are still insufficient. Also need specialized validation verification body to have the authority of certification on accessibility and verifiability of the project, but according to the current market situation [11], the project is still mainly identified by the foreign third party's verification and certification bodies. Although some of the country's third party project certification is started, due to the time of entering the market is late, lacking insufficient validation verification of experience, and verification of certified area scope nor third parties abroad.

4) Slow development of carbon financial products and financial services [12]. Carbon market in China has great potential for growth and development space, but in carbon finance and carbon finance development is relatively backward, little quantities and type of carbon financial products and services. On the one hand, the traditional financing tools, such as low-carbon industrial investment fund, the Green Carbon Fund, low-carbon bond, low carbon trust venture capital participation are not high [13]. On the other hand, although domestic financial institutions develop quickly on green credit, green stock and insurance projects, in which the green business has great develop advantages. Green lending refers to curb blind expansion of energy-intensive and high pollution industries, and promotes the loans for energy saving, emission reduction and protection of the environment on the project investment. But green credit's share of the total scale of China's bank credit is small, and lack of specific green credit Guide Directory, maneuverability is not strong [14]. Compared to European and American banks act frequently in direct investment, bank loans, carbon trading, carbon options futures and other aspects, China stops at "green credit"- the shallow level, and lack of complementary products.

5) Lack of carbon trade pricing power. Although China is the largest supplier of carbon emission, in international carbon financial transactions markets which are based on in the carbon dioxide emissions quotas markets are at a disadvantage [15]. Due to the main mode of our participation in the international carbon finance is the clean development mechanism, and EU countries have become the main buyers under the clean development mechanism projects, so this inequality of status courses China lost activity and pricing power in the global carbon trading market. The other hand, due to the carbon trading market in China is still in its infancy stage, carbon market's related infrastructure construction is not perfect, such as regulations and policies, and training does not 
meet the needs for the development of carbon markets, compared to those mature markets which have been implemented for several years in Europe and America, remains China is still a participant in the international carbon trading market at present, and has no pricing power.

\section{Conclusion}

In a word, the development of carbon finance in our country cannot be achieved overnight; we need to constantly learn from the successful experience of other countries in the development process, and continue to find our own problems. In general, to achieve the goal of energy saving and emission reduction and low carbon development road, there is a closely relationship between economic growth and greenhouse gas emissions. The government needs to size up the situation, take effective measures in energy saving and emission reduction, promote the transition to a low carbon economy, more importantly, actively develop carbon finance, strengthen carbon finance idea, accelerate carbon financial product innovation, and establish scientific and effective carbon finance financing system [16]. Now the world's carbon financial system is not a smooth development, and it bristles with difficulties. We would like to emphasize here that international cooperation to promote the development of carbon finance has been insufficient. The differences in emission reduction targets, regulatory systems and market construction led to the development of market segmentation, policy risk and high transaction costs. But looking from a long-term point of view, although the development of carbon financial barriers may exist for a long time and have a negative effect, the carbon finance development task is arduous, but with emerging international consensus and increasing degree of international cooperation, the carbon finance market has been developing rapidly; for example, the bank develops carbon financial derivative products, implements the carbon innovation in financial services, and promotes low-carbon concept actively. Between countries due to different national conditions, development conditions are different. There are disputes over certain international emission reduction conventions, but we need to understand that energy-saving emission reduction is the trend of the times, differences do not change the trend of global cooperation, international carbon trading market will enter a new stage of development, and at the same time, China's carbon finance under the good international environment will have a good future. We will certainly realize the goal on common development of economy, society and ecology.

\section{Suggestions on the Development of China's Carbon Financial Market}

\subsection{Fully Recognize the Urgency of the Development of Carbon Finance, Intensify Policy Support}

Carbon financial system is composed of three organic parts, including carbon financial market system, carbon financial service system and carbon financial organization system of policy support [17]. If there is no strong policy support, carbon financial market system and service system cannot be established. Therefore, according to the principles of sustainable development needs the government and regulators called for targeted standards, rules and establish a mature system of carbon trading and the interests of the scientific and reasonable compensation mechanism; implementation of carbon budget system, constructs the multi-level carbon trading system and the core competence of extremely carbon financial service system; vigorously promote domestic market by the voluntary emission reduction willing to join voluntary emissions "gradually to" voluntarily join, mandatory cuts "(part) forced to join, mandatory cuts" stage; strengthen domestic carbon trading platform integration, the process of the carbon in the positive development of regional financial centre, on the basis of the comprehensive development of cultivating national carbon financial center, and create favorable conditions for building the international carbon finance center [18]. At the same time, we should contribute to the carbon emissions exchange act, specifically including trade subject, the subject matter, carbon emissions initial allocation, carbon emissions rights transfer, and carbon emissions trading regulation mechanism, legal liability and other legal requirements and operation rules, and provides the corresponding investment, tax, credit, personnel, evaluation and other supporting policies.

\subsection{To Speed up the Cultivation and Construction of Carbon Trading Platform and Mechanism, to Create Environment for Carbon Finance Development}

First is to speed up the government's boundary and properties of carbon emission rights laws that encourage carbon emission rights has become a real financial assets, available for financing, collateral or guarantee to exert 
carbon assets credit creation function to provide institutional guarantee. Second is combination of parts is going to carry out compulsory pilot emissions trading, developing on the basis of the key industries total emission control of emissions from stock trading system as soon as possible, and provide trading places for the development of carbon finance [19]. Third is to build the differential carbon market pricing mechanism, in the realization of effective competition and optimal allocation of emission rights of at the same time, provides the price basis for the carbon financial products transactions. Fourth is deducted by fiscal interest discount, tax breaks and accelerated depreciation, investment, credit, extraction ways to provide incentives, such as risk fund security, improve the financial institutions and enterprises to carbon trading and carbon financial participation, support for its sustainable development.

\subsection{Cultivate Carbon Financial Intermediaries and Low-Carbon Development and Innovation Project Products}

At present, the right of carbon emissions has very big financial attributes. Around these carbon credits to form carbon futures, currency, bank of carbon, carbon credits trading carbon and other financial derivative products, has become an important direction of business innovation of financial institutions. Want to combine project for energy conservation and emissions reduction credits pledge financing loans, explore the development of financial products linked to carbon emissions, carbon funds entrusted management. To strengthen the investment of new energy credit and low carbon technology investment. To actively innovative low carbon credit products, such as discharge permit as collateral for the environmental protection enterprise financing, offer for CDM project fund settlement services. To learn the advanced international Banks in the "carbon finance" market and "carbon bank" service experience and practice, actively explore "carbon credits" innovation system [20].

And carbon trading project contains a huge demand for financial inter-mediation services, should encourage non-governmental organizations and financial institutions as a financial intermediary and trading intermediary role, allow financial intermediaries to project owners to provide financing lease, financial advisory, capital account management, purchase, or to participate in the joint development of CDM projects and other services. At the same time, should actively cultivate carbon trading specialized talents, cultivating professional carbon financial consultation, evaluation, law, accounting and other intermediary agencies, provide professional intermediary services for carbon finance each link.

\subsection{To Strengthen International Cooperation in Carbon Financial Markets, the Establishment of Carbon Finance in China}

Market is the primary stage of the development of carbon financial markets, in order to realize the maximization of the China enterprise carbon trading interests abroad, participate in international competition, an important problem is to implement the domestic carbon financial markets and the international carbon finance market. In this goal, driven by China's carbon financial market should focus on the future, banking, insurance, securities industry first in-depth exchanges and cooperation with foreign carbon financial institutions, to industry rules, small to a specific project audit, running and so on. Focus on foreign carbon financial frontier dynamic, carbon exchanges with foreign cooperation, the introduction of foreign advanced trading mechanism, trading rules. From another perspective, which will be conducive to China's carbon financial market, the fastest speed in the shortest time with the international carbon market, also will be good for the reform, development and innovation of China's financial markets.

\subsection{Actively Promote the Internationalization of RMB}

At present, on the issue of carbon trading for pricing or account settlement currency, the euro is ahead. Global carbon fund has reached 2007, 58, funds of 7 billion euros ( $\$ 9.5$ billion). With investors' money from the government is $93.3 \%$ and $84.7 \%$ of a hybrid buyer for the euro, private investors' money $60.19 \%$ for the euro. The international carbon trading the euro denominated settlement needs improving in recent years. With the constant improvement of the national participation in carbon market is, there will be more and more countries improve their currencies on carbon trading express in the position in the international monetary system, accelerating towards the world's leading international currency. As the world's largest CDM a seller's market in our country, we must seize the opportunity, to bind the renminbi and carbon emissions, to promote carbon trading renminbi internationalization. 
In short, in the modern economic system, finance is the core of the economy. Carbon finance not only provides a variety of means of support to the development of low carbon economy, but also offers a new development space for the innovation of the financial system. Therefore, the development of low carbon economy is dependent on the carbon financial market development and innovation. Carbon finance is the development of low-carbon economy, which is one of the important guarantee conditions for the construction of ecological civilization, and is also a low carbon economy development, promoting the important breakthrough of carbon emissions. Carbon financial market has just started in China, coincided with a low carbon economy era. It is a rare historical opportunity, and the carbon market system has preliminarily established. China's carbon reduction potential is tremendous, and has very good prospects for development. We should face the problems and challenges, make efforts to reform, improve the policy system, cultivate and innovate financial products, perfect carbon intermediary market, set up a supervision mechanism and incentive mechanism, to better develop carbon financial market, promote the development of low-carbon economy, and build a resource-conserving society in an all-round way and environment-friendly society.

\section{References}

[1] Qiao, L.J. and Jiang, X.M. (2012) The Significance of Developing Low Carbon Economy and Carbon Finance in the New Era, the Dilemma and Path Choice. Economist, No. 4, 32-34.

[2] Li, X.N., Feng, J.J., Huang, X.M., Wang, L.J. and Lun, X.B. (2010) Financial Innovation in the Era of Low Carbon Economy-2010 Financial Innovation Forum. Summary Financial Aspect, No. 7, 70-72.

[3] Liu, X.L. (2012) Low Carbon Economic Development Needs Financial Innovation to Support. Guangming Daily Weekly Magazine, No. 2, 46-47.

[4] Ren, W.F. (2008) Low Carbon Economy and Environmental Finance Innovation. Shanghai Economic Research, No. 3, 33-35.

[5] Chen, R.X. (2010) Carbon Finance Innovation in Low Carbon Era: A Case Study of Industrial Bank. China's Economic and Trade, No. 22, 71-73.

[6] Xie, X.H. (2010) Research on the Theory of Financial Innovation in the Development of Low Carbon Economy. Theoretical Research, No. 5, 21-23.

[7] Weng, Q.Y. and Liu, L.W. (2010) Review of Carbon Finance Research from the Perspective of Low Carbon Economy. Financial Development Research, No. 8, 52-54.

[8] Liu, Q. and Wang, Y. (2010) Carbon Finance Market: Global Situation, Development Prospects and China’s Strategic. International Financial Research, No. 9, 33-35.

[9] Zhou, P.J. and Chu, C.X. (2010) Carbon Finance: Financial Innovation in the Era of Low Carbon Economy. Finance and Economy, No. 2, 11-13.

[10] Wang, Z.W. (2010) Promoting the Innovation and Development of Carbon Finance Tools. Chinese Economic Report, No. 1, 66-68.

[11] Zou, Y.S. (2010) Chin's Low Carbon Finance Development in the Background of Low Carbon Economy. China Finance, No. 4, 36-37.

[12] Labatt, S. and White, R.R. (2001) Carbon Finance-The Financial Implications of Climate Change.

[13] He, D.X. and Shi, X.L. (2012) China’s Carbon Financial Service System. Journal of Hubei University of Economics, No. 3, 66-67.

[14] Weng, H.J. (2013) Carbon Financial Service System Symbiotic Network Construction Research. Hubei Social Sciences, No. 1, 28-30.

[15] Chen, X.Y. and Feng, Z.Y. (2013) International Experience of Carbon Finance Development and Its Revelation. Journal of Guangzhou University (Social Science Edition), No. 9, 11-13.

[16] Xiong, F. (2013) China Carbon Financial Market Development Countermeasures and Suggestions. Business Herald, No. 6, 49-50.

[17] Shu, D. (2010) Obstacles and Policies for China's Carbon Finance Development. Wuhan Finance, No. 7, 39-40.

[18] Li, T., Li, C.W. and He, J.F. (2010) The Status Quo of International Carbon Trading Market and the Prospect of China’s Carbon Trading Market. Economic Aspect, No. 7, 69-71.

[19] Chen, X.Y. (2014) The Problems and Strategies of China’s Carbon Financial Market Development. China Trade, No. 9, 28-29.

[20] Wang, Q., Li, T. and Wang, Y.X. (2010) Development Strategy and Path Analysis China Carbon Finance. Social Science Journal, No. 3, 55-57. 